Volume 102 Number 914

International

Review

of the Red Cross

Humanitarian debate: Law, policy, action
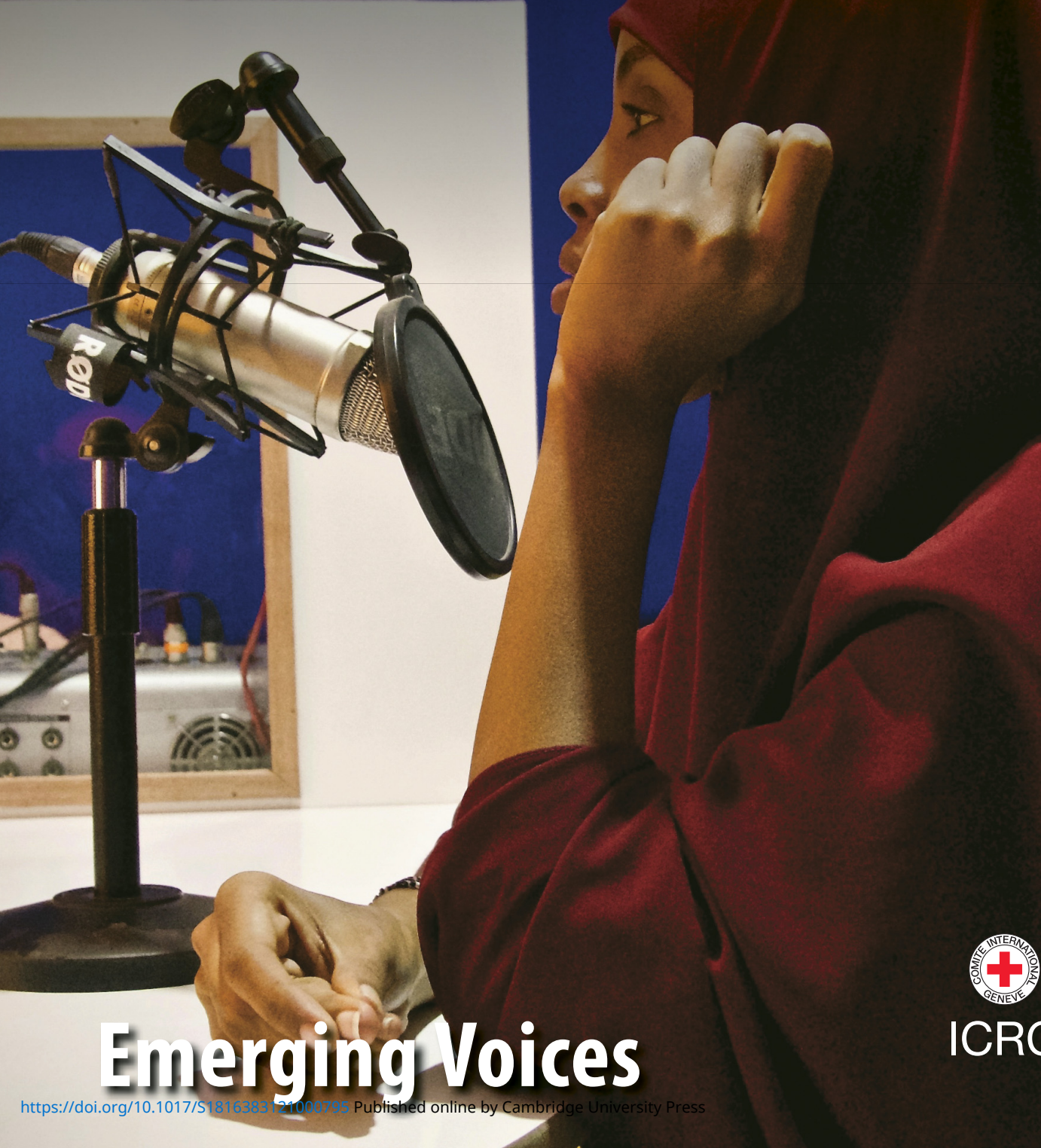

ICRC 


\section{International Review}

of the Red Cross

\section{Aim and scope}

Established in 1869, the International Review of the Red Cross is a peer-reviewed journal published by the ICRC and Cambridge University Press. Its aim is to promote reflection on humanitarian law, policy and action in armed conflict and other situations of collective armed violence. A specialized journal in humanitarian law, it endeavours to promote knowledge, critical analysis and development of the law, and contribute to the prevention of violations of rules protecting fundamental rights and values. The Review offers a forum for discussion on contemporary humanitarian action as well as analysis of the causes and characteristics of conflicts so as to give a clearer insight into the humanitarian problems they generate. Finally, the Review informs its readership on questions pertaining to the International Red Cross and Red Crescent Movement and in particular on the activities and policies of the ICRC.

\section{International Committee of the Red Cross}

The International Committee of the Red Cross (ICRC) is an impartial, neutral and independent organization whose exclusively humanitarian mission is to protect the lives and dignity of victims of war and other situations of violence and to provide them with assistance. It directs and coordinates the international activities conducted by the International Red Cross and Red Crescent Movement in armed conflict and other situations of violence. It also endeavours to prevent suffering by promoting and strengthening international humanitarian law and universal humanitarian principles. Established in 1863, the ICRC is at the origin of the Movement.

\section{Members of the Committee}

President: Peter Maurer

Vice-President: Gilles Carbonnier

Mauro Arrigoni
Hugo Bänziger
Rémy Best
Edouard Bugnion
Jacques Chapuis
Melchior de Muralt
Christoph Franz
Katja Gentinetta
Maya Hertig Randall

Alexis Keller

Jürg Kesselring

Laura Sadis

Doris Schopper

Béatrice Speiser

Bruno Staffelbach

Suba Umathevan

Barbara Wildhaber
Editorial Team

Editor-in-Chief: Bruno Demeyere Thematic Editor: Ash Stanley-Ryan Editorial Team: Sai Venkatesh Special thanks: Juana Acosta-Lopez; Monia Ammar; Cordula Droege; Robert McLaughlin; Mamadou Sow and all anonymous peer reviewers

International Review of the Red Cross 19, Avenue de la Paix, CH 1202 Geneva CH - 1202 Geneva

$\mathrm{t}+41227346001$

e-mail: review@icrc.org

Editorial Board

Monia Ammar

Magistrate Counselor, Cassation Court, Tunisia

Lorraine Anderson

Canadian Human Rights Commission, Canada Cécile Aptel

The United Nations Institute for Disarmament Research, Geneva

Tarciso Dal Maso

Legislative Adviser of Brazilian Senate, Brazil

Adama Dieng

Former UN Under Secretary General, Senegal

Gloria Gaggioli

Geneva Academy of International Humanitarian Law and Human Rights, Switzerland

Emanuela-Chiara Gillard

Institute for Ethics, Law and Armed Conflict, University of Oxford, UK

Juana Acosta López

Universidad de La Sabana, Colombia

Jihyun Park

Youngsan University, Korea

Bimal Patel

Rashtriya Raksha University, India

Mariana Salazar

Universad Iberoamericana, Mexico

Soliman M Santos Junior

Judge, Regional Trial Court of Naga City,

Philippines

Michael Schmitt

University of Reading, United Kingdom

Sandesh Sivakumaran,

Lauterpacht Centre, University of Cambridge

Orly Stern

Institute for Ethics, Law and Armed Conflict,

University of Oxford, UK

Folake Tafita

University of Ibadan, Nigeria

Bakhtiyar Tuzmukhamedov

Russian Association of International Law, Russia

Yvette Yegenhagen

Australian Red Cross, Australia

Lijiang Zhu

China University Political Science and Law, China

Cover Photo: Mogadishu, Mustaqbal radio station. The ICRC and the Somali Red

Crescent Society are working with a local radio station to encourage everyday habits that will help keep diseases, like acute watery diarrhea and cholera, away. An actress recording. Photographer: MOHAMED, Abdikarim. Credit: ICRC. 


\section{CONTENTS: Volume 102 Number 914}

\section{Emerging Voices}

511 Editorial: Emerging Voices: Increasing the diversity of voices featured in the International Review of the Red Cross

Bruno Demeyere

515 Closer to home: How national implementation affects State conduct in partnered operations

Alessandro Mario Amoroso

539 Destructive trends in contemporary armed conflicts and the overlooked aspect of intangible cultural heritage: A critical comparison of the protection of cultural heritage under IHL and the Islamic law of armed conflict

Victoria Arnal

559 Armed escorts to humanitarian convoys: An unexplored framework under international humanitarian law

Annabel Bassil

579 Greener insurgencies? Engaging non-State armed groups for the protection of the natural environment during non-international armed conflicts

Thibaud de La Bourdonnaye

607 Collaborating with organized crime in the search of disappeared persons? formalizing a humanitarian alternative for Mexico Issa Cristina Hernández Herrera

629 For whom the bell of proportionality tolls-Three proposals for strengthening proportionality compliance

Won Jang

659 Liar's war: Protecting civilians from disinformation during armed conflict

Eian Katz

683 Humanizing siege warfare: Applying the principle of proportionality to sieges

Maxime Nijs 
705 The role of international humanitarian law in the search for peace: Lessons from Colombia César Rojas-Orozco

721 Behind the legal curtain: Social, cultural and religious practices and their impact on missing persons and the dead in Colombia Mayra Nuñez Pastor

745 The International Committee of the Red Cross and the International Criminal Court: Turning international humanitarian law into a twoheaded snake?

Fernanda García Pinto

765 "Or any other similar criteria": Towards advancing the protection of LGBTQI detainees against discrimination and sexual and genderbased violence during non-international armed conflict Vaughn Rossouw

789 Investigating the Jana Adalat of the 1996-2006 armed conflict in Nepal Yugichha Sangroula

807 Whose perception of justice? Real and perceived challenges to military investigations in armed conflict

Claire Simmons

823 Automating occupation: International humanitarian and human rights law implications of the deployment of facial recognition technologies in the occupied Palestinian territory Rohan Talbot

851 A legal obligation under international law to guarantee access to abortion services in contexts of armed conflict? An analysis of the case of Colombia Juliana Laguna Trujillo

875 The redirection of attacks by defending forces Tsvetelina van Benthem

893 Who is a civilian in Afghanistan? loanna Voudouri

923 Jus ex bello and international humanitarian law: States' obligations when withdrawing from armed conflict

Paul Strauch and Beatrice Walton

959 Indigenous Australian laws of war: Makarrata, milwerangel and junkarti

Samuel White and Ray Kerkhove 